\title{
The Application of Judicial Precedents as a Way to Reduce Brazilians Tax Lawsuits
}

\author{
Renato Lopes Becho* \\ Pontificial Catholic University of Sao Paulo, Sao Paulo, Brazil \\ Email: renatobecho@uol.com.br
}

How to cite this paper: Becho, R. L. (2020). The Application of Judicial Precedents as a Way to Reduce Brazilians Tax Lawsuits. Beijing Law Review, 11, 729-739. https://doi.org/10.4236/blr.2020.113044

Received: July 2, 2020

Accepted: September 14, 2020

Published: September 17, 2020

Copyright $\odot 2020$ by author(s) and Scientific Research Publishing Inc. This work is licensed under the Creative Commons Attribution International License (CC BY 4.0).

http://creativecommons.org/licenses/by/4.0/ (c) (i) Open Access

\begin{abstract}
This article aims to analyze the thesis that the application of the doctrine of precedent, originated in England, could reduce judicial litigation in Brazil, mainly in tax law procedures, such as tax enforcement. Brazil Law applies Civil Law, which means that the law is based on the principle of legality. However, the Brazilian Judiciary System is costly and has lower effectiveness. To deal with these problems, the National Congress has changed the law, providing mechanisms from the Common Law, mainly by introducing the binding precedents system. Respect for precedent is a requirement of the Brazilian Civil Procedure Code of 2015. However, the theory of precedent was developed in a society culturally very different from the Brazilian, which leads to the need for comparisons such as the exposed here that will justify the differences facing the source procedure that will undoubtedly occur. However, there are doubts if the transformation of the legal system will reduce the impressive figures of judicial cases. Nevertheless, the conclusion is definite. The precedent theory involves techniques that can potentially reduce tax lawsuits, representing a significant number of all legal disputes in Brazil. This conclusion was reached through data analysis, some doctrinal sources, and, mainly, by the author's reflections. This mix of scientific method verifies the hypothesis: describes and analyses the system and presents a definite conclusion.
\end{abstract}

\section{Keywords}

Comparative Law, Judicial Precedent in Brazil, Civil Law, Common Law, Tax Enforcement

*Bachelor in Law at UFMG (Belo Horizonte, Brazil, 1990), specialist of Co-operatives at UNISINOS/RS (1994), Master of Tax Law (1997) and PhD of tax Law (2000) at Pontifícia Universidade Católica de São Paulo (PUC/SP). Visiting research at King's College, London (2016). Tax Law Professor at PUC/SP. Federal Judge in São Paulo/SP, Brazil. 


\section{Introduction}

Brazilian Law uses a Civil Law (or European Continental Law) system, on which statutes and codes approved by the Parliament are the essential legal grounds. The principle of legality emanates in article $5^{\text {th }}$, and incises II from the Federal Constitution: "no one shall be obliged to do or refrain from doing something except by virtue of law"1. Law must be interpreted, in this context, as a statute ${ }^{2}$.

In Tax Law the principle of legality is confirmed for another constitutional command:

Article 150. Without prejudice to any other guarantees ensured to the taxpayers, the Union, the states, the Federal District and the municipalities are forbidden to:

I-impose or increase a tribute without a law to establish it ${ }^{3}$.

On the other hand, the most crucial source of the Law in the Common Law system is the judicial precedent; so much that judge-made Law is a synonym to Common Law.

Even though Brazil applies Civil Law and its codes, some recent new legislation and the way as judges are judging, which shows that the statutes may not be the only source of Law as it was in the past. In 2004 a Constitutional Reform Act introduced binding súmulas (dockets of jurisprudence; extracts that summarize decisions from a Court, showing a stare decisis) from the Supreme Court, while the Civil Procedure Code (CPC) from 2015 contains, generally speaking, binding judicial precedents. Because of that, Brazil is approaching Common Law in one point (doctrine of precedent), hence showing that we are in a pivotal moment of Brazilian legal history.

At least in one crucial subject (tax enforcement), the application of the doctrine of precedent could reduce the vast number of judicial cases in Brazil, since tax enforcement represents more than one-third of them. Nevertheless, there will be a long-term adjustment until the Brazilian Legal system can reach a secure and foreseeable law.

\section{The Impressive Figures about the Brazilian Judiciary System}

Brazil is the fifth largest country and the fifth most populous in the world. In part, as a result, the Brazilian Judicial System has some impressive numbers: ${ }^{1}$ Constitution of the Federative Republic of Brazil. $3^{\text {rd }}$ edition. Biblioteca Digital da Câmara dos Deputados. Brasília: 2010, p. 15. Available at http://english.tse.jus.br/arquivos/federal-constitution. ${ }^{2}$ See, for instance, another article from the Brazilian Constitution: "Article 59. The legislative process comprises the preparation of: I-amendments to the Constitution; II—supplementary laws; III—ordinary laws IV-delegated laws; V-provisional measures; VI-legislative decrees; VII-resolutions. Sole paragraph. A supplementary law shall provide for the preparation, drafting, amendment, and consolidation of laws". Constitution of the Federative Republic of Brazil. $3^{\text {rd }}$ edition. Biblioteca Digital da Câmara dos Deputados. Brasília: 2010, p. 61-62. Available at http://english.tse.jus.br/arquivos/federal-constitution.

${ }^{3}$ Constitution of the Federative Republic of Brazil. $3^{\text {rd }}$ edition. Biblioteca Digital da Câmara dos Deputados. Brasília: 2010, p. 111. Available at http://english.tse.jus.br/arquivos/federal-constitution. 
with jurisdiction over more than 208 million people ${ }^{4}$, there are more than 1 million lawyers, 3 million holders of law degrees, and the breathtaking amount of half of the world's law schools 5 .

Brazil is a federal republic with 26 states, one federal district and 5570 counties. There are 1570 courts of first instances, as well as 91 appellate courts (86 state and 5 regional-federal Courts). Jurisdiction in the Brazilian court system is divided in four main areas (Justice, Labor, Military, Electoral). As a result of that, there are 4 Superior Courts (Justice, Labor, Military, Electoral) and one Supreme Court. In total, there were 17,349 judges $^{6}$, and 18.011 judges in 2016 in Brazil $^{7}$.

Astonishingly, in 2015 the Judiciary spent $1.3 \%$ of the national GDP ${ }^{8}$, and $1.4 \%$ in $2016^{9}$. To compare it with other countries, in 2015 Argentina spent $0.12 \%$, the US and England $0.14 \%$ each and Germany $0.32 \%{ }^{10}$.

In 2015 there were 27.3 million new cases brought in court (2.6 million of them were tax enforcement) and 28.5 million cases were finished ${ }^{11}$. However, 2016 still started with 74 million judiciary cases in progress ${ }^{12}, 39 \%$ of which are cases of tax enforcement (28.8 million “old" cases) ${ }^{13} .2016$ finished with 79.7 million judicial lawsuits.

In tax law, there are criminal cases and civil cases, and there are administrative judgments and judicial judgments. In the case of judicial proceedings, there are a few different procedures. For instance: Judicial Review (to discuss the legality of an administrative act; the judge can issue a writ of mandamus etc.), declaratory process (used when the taxpayer does not feel that he or she is required to pay a tax), annulment process (when the taxpayer wants to cancel an assessment), and, tax enforcement (when the tax administration has no evidence that the tax due was paid). All of those processes start at the first jurisdiction. If the tax in discussion is collected by a municipality, a state or the Federal District, it is the state judge's jurisdiction. On the other hand, if the tax is collected by the Union, a federal judge has the jurisdiction to conduct and to adjudicate it.

In all of these procedures, there are a number of different appeals available. They will be presented to a second level Court. Again, if the tax is due to a municipality or a state, the jurisdiction to decide is a state court. All Brazilian states have a state court. However, if the tax is due to the Union, the appeal will be de${ }^{4}$ According to https://en.wikipedia.org/wiki/Brazil. Access on February 28, 2019.

${ }^{5} \mathrm{~J}$. Kravchychyn. Brasil, sozinho, tem mais faculdades de direito que todos os países. October 14th, 2010. Available at https://www.oab.org.br/.

${ }^{6}$ Justiça em Números 2016 (ano-base 2015), p. 31.

${ }^{7}$ Justiça em Números 2017 (ano-base 2016), p. 35.

${ }^{8}$ Justiça em Números 2016 (ano-base 2015), p. 33.

${ }^{9}$ Justiça em Números 2017 (ano-base 2016), p. 65.

${ }^{10} \mathrm{Da}$ Ros, Luciano. O custo da Justiça no Brasil: uma análise comparativa exploratória. "Newsletter. Observatório de elites políticas e sociais do Brasil". NUSP/UFPR, v. 2, n. 9, julho de 2015, p. 4.

${ }^{11}$ Justiça em Números 2016 (ano-base 2015), p. 62.

${ }^{12}$ Justiça em Números 2016 (ano-base 2015), p. 43.

${ }^{13}$ Justiça em Números 2016 (ano-base 2015), p. 61. 
cided by one of five federal circuit (regional) courts.

There is a special court above all of these 27 states and Federal District courts and 5 Federal Circuit Courts named the Superior Court of Justice (Portuguese acronym: STJ). Finally, the fourth instance is the Supreme Court (STF). In view of the fact that the tax law is extensively mentioned by the Federal Constitution, it is common that tax cases are finally decided only at the STF.

\section{Comparing Supreme Courts}

It is difficult to compare the Judiciary from different countries, with different cultures, legal systems as well as complexities. On the other hand, when comparing some courts, sometimes it can be useful to present elements of comparison, as a didactical exercise, so that the reader can have an idea of the subject she or he is reading about. With this in mind, some relevant data from Supreme Courts will be presented.

The Brazilian National Congress imported the binding judicial precedents from England. As a result of it, it is interesting to compare Supreme Courts from Common Law jurisdiction and the Brazilian Supreme Court. It can illuminate the debate between these two judicial systems.

The UK Supreme Court is composed of 12 Justices and has jurisdiction over England, Wales, Scotland and North Ireland. The first two countries of them apply common law and the others two apply civil law. The Court analyzed, between 1 April 2014 to 31 March 2015, 231 lawsuits ${ }^{14}$.

The US Supreme Court is composed of 9 Justices. Apart from the Louisiana and California Civil Codes, for example, the majority of the States follow the common law. There are around 7000 requests to hear cases per year, but the Court only hears around 80 cases and decides another 50 without hearing arguments ${ }^{15}$.

The Brazilian Supreme Court, consisting of 11 Justices, applies only civil law for the whole country. It has analyzed, between 1 January to 31 December of 2014, 110,603 lawsuits ${ }^{16}$.

This figure illustrates the reason of why the Brazilian National Congress identifies the Common Law as an inspiration to change judicial system. However, there are some cultural aspects in Brazil that can contribute to so many lawsuits. The new law tries to deal with them.

\section{Some Challenging to Improve the Brazilian Judicial System}

Starting with a positive aspect, the Brazilian Federal Constitution (Article $5^{\text {th }}$, incise XXXV-" "the law shall not exclude any injury or threat to a right from the

${ }^{14}$ United Kingdom, The Supreme Court Annual Report and Accounts 2014-2015, 26. Available at https://www.supremecourt.uk/docs/annual-report-2014-15.pdf.

${ }^{15}$ According to The Leadership Conference. Available at https://civilrights.org/judiciary/federal-court-system/u-s-supreme-court/.

${ }^{16}$ Brazil. Notícias do STF (December 12th, 2014). Available at http://www.stf.jus.br/. 
consideration of the Judicial Power" ${ }^{17}$ ) ensures that access to the Judiciary is free. In that sense, if someone does not have money to pay legal fees and can prove this with simple deeds, she or he can starts a case for free. There are public lawyers or practitioners (law students with a teacher as a supervisor, for example) available if someone does not have money to pay for a lawyer. It is also accessible to appellate to a second instance court, granted for the principle of due process of law (which includes a judiciary revision from a prior judiciary decision). However, there are some hurdles to accessing higher levels of courts $^{18}$.

On the other hand, many people use the Judiciary to postpone their duties, starting with public administration at all levels (federal, states, and municipalities). Since they do not need to pay Judiciary duties if they lose cases, they just needed to pay low fees to the winning party. If the losing party is not a public administration body, they need to pay higher fees for the winning party. Despite this, many big companies (e.g. telephonic groups) seem to mimic governments and use the Judiciary to postpone their obligations. Because of that, it is not a surprise that there are so many lawsuits in Brazil, as was shown above.

One good point in the new Civil Procedure Code (2015) is that the government will pay progressive judiciary fees for the winners (article 85). Maybe they would start fewer lawsuits when they know that there is a lower chance of winning.

Parliament could implement maybe other hurdles to accessing higher-level courts, but the Brazilian Bar Association-OAB, an influential association, would likely oppose this.

Another important aspect is that judges in Brazil fee free to make decisions using their motivation. However, Brazil has a large Constitution flooded with principles, some of which are opposed to each other, this behavior can be problematic. In the same way as Ronald Dworkin and Robert Alexy, Portuguese Professor J. J. Gomes Canotilho has shown ${ }^{19}$ that some principles "survive" despite their conflicting nature because interpretation can "balance" them. Therefore, it is not difficult to make a decision motivated by one or another principle. In addition, some statutes are general, while others tend to be more specific. Then, again, it is not impossible to apply one statute instead of another.

As a result of this situation, it is not a surprise that judicial decisions in Brazil apply statutes differently, a behavior that might lead to injustices. For the same situation, one person can receive a ruling that gives her or him a right, and another person can receive a ruling that does not give her or him the same right. Another problem is that litigants have been stimulating to introduce legal remedies, hoping for a "good" decision at one of the Brazilian Judiciary four

${ }^{17}$ Constitution of the Federative Republic of Brazil. $3^{\text {rd }}$ edition. Biblioteca Digital da Câmara dos Deputados. Brasília: 2010, p. 17. Available at http://english.tse.jus.br/arquivos/federal-constitution. ${ }^{18}$ Nowadays, Congress is debating a Constitutional Amendment Project to introduce more hurdles to access the Superior Court of Justice-STJ.

${ }^{19}$ Direito Constitucional. Coimbra: Almedina, 1991, p. 545. 
instances.

Historically, judges in Brazil do not pay much attention to judicial precedents. However, more than this, there is a greater cultural problem: judges, from all levels, are not concerned about the inconsistencies in the decision-making processes among them and other judges. I would like to refer to a personal experience to demonstrate this point, considering it is difficult to prove this affirmation. New Brazilian judges need do stay in a court school normally for 4 months when they start the job. They attend classes and work part time in courthouses. One of these new judges once told me, very proudly, that he had reviewed a decision from another senior judge that day. I asked him if the previous decision was "wrong" and the answer was: "no, but I think differently!" Obviously, in a country like Brazil that has more than 18.000 judges, this is a huge problem. Since it is difficult to enquire into so many judges, we focused above on the Supreme Court.

Trying to exemplify the fact that Brazilian judges do not see ruling and decisions as a precedent in the sense that it works in Common Law, at least two justices from STJ published their uneasiness in opinions or at conferences that focused on this point. The Superior Court of Justice-STJ is a third instance court below the Supreme Court, just one court that is higher than 32 state and 5 federal-regional courts, with 33 justices. The STJ has the constitutional obligation to unify federal interpretation of law (Federal Constitution 1988, Article 105, III, "c"). According to the Act 13.762 of 2012, each Justice of the STJ has 8 clerks. However, 5.175 people work at the Court ${ }^{20}$. In 2018, the STJ received 346,337 cases and decided on $524,801^{21}$.

José Delgado, now a former justice of STJ, at a conference about Tax Law stated that he had identified in a brief research he had done at least 33 points where the same Court applied different, conflicting decisions. He expressly talked about the "unpredictability of judicial decisions"22.

Humberto Gomes de Barros, another former justice of the STJ, said how sad he was that the court was not abiding by its own precedents ${ }^{23}$. The court was reviewing a non-binding (but with persuasive power) summula just three months after having approved it! He spoke in a judgment known as banana boat.

We are leaders and I- a Justice in a Court whose decisions the Justices themselves do not respect-I feel myself saddened. As a taxpayer, what I am too, I dive in insecurity, as a passenger from that tragic flight where the pilot was lost in the middle of the night on top of the Amazonian jungle.

Now we are reviewing a summula that we approved less than three months ago. Now we are saying that it is wrong because someone gave us a lesson saying

\footnotetext{
${ }^{20}$ Brazil. Justiça em Números 2018 (ano-base 2017).

${ }^{21}$ Brazil. "Relatório Estatístico de 2018".

22“A imprevisibilidade das decisões judiciais”.

${ }^{23}$ Brazil. Superior Tribunal de Justiça, AgRg-REsp 382.736-SC, publ. March $3^{\text {rd }}$, 2011. Available at http://portal.stf.jus.br/.
} 
that this summula shouldn't have been written this way.

On tourist beaches all over the world there is a game with a huge floating banana, filled with people dragged by a boat. The duty of the pilot is to drop everybody off the float. To do that, the boat goes straight forward and then and suddenly makes curves of almost ninety degrees. The game only finishes when every passenger in the float ends up in the sea. Well, this Court seems to have taken over as the pilot of the boat. Our duty has been to drop off the citizen.

We have no doubt that all these rulings that the Justices talked about were justified. The problem is how judges are applying the principle of liberty to motivate their decisions. They don't respect the previous decisions, including their own Court's, something that creates immense insecurity.

It shows, in other words, that judges do not think that they need to adhere to binding precedents. Judges simply (or just) interpret the statutes in the way they prefer. With the new CPC, Congress shows to judges that Brazilians would like to see things done differently. By the Brazilian Civil Procedure Code from 2015, presented in the next item, judges and justice shall consider binding precedents in the adjudication processes.

\section{New Brazilian Civil Procedure Code along with a Brief History of Precedents in Brazil}

The year of 2015 marks an important statutory alteration in Brazil: the new Civil Procedure Code $(\mathrm{CPC})^{24}$. Unlike its predecessor (Civil Procedure Code from 1973), the new Law conveys rules about the use of judicial precedents ${ }^{25}$. This paper will talk about few of the 1.072 articles.

Article 15 determines that CPC applies to administrative procedures (not judiciary procedures) that are very common in Tax Law and Competition Law, for instance. Starting from now on, administrative procedures are going to use the CPC rules as well, including applying binding judicial decisions in administrative courts, such as the Economic Law Administrative Council-CADE, with competence to decide about competition law, and Federal Administrative Council of Tax Legal Appeals-CARF.

Article 489 determines what is essential in a judicial decision and, for the first time in Brazil, the doctrine of precedents is introduced. Paragraph 1 of this ar-

${ }^{24}$ Law n. 13.105, from March $16^{\text {th }}$, that took effect in March 2016.

${ }^{25}$ As an effect of this novelty, now a days many British jurists are studied in Brazil. It is the case of Neil Andrews, $O$ modern processo civil: formas judiciais e alternativas de resolução de conflitos na Inglaterra; James Lee (edicted), From House of Lords to Supreme Court. judges, jurists and the process of judging, Joseph Raz, Between Authority and Interpretation; Colin Manchester and David Salter, Manchester and Salter on Exploring the Law. the dynamics of precedent and statutory interpretation; Neil Duxbury, The Nature and Authority of Precedents, Cross and Harris, Precedent in English Law, Cross, Statutory Interpretation; Michael Zander, The Law-Making Process. Luiz Guilherme Marinoni produced an interesting analysis in A Ética dos Precedentes. justificativa do novo CPC. See, also, William Baynard Meissner, How to Explain Brazilian Civil Procedure in English. 
ticle $^{26}$ estipulates that "No judicial decision, whether interlocutory, ruling or judgment, shall be considered to be justified, which" [...] "limit itself to invoke a precedent or súmula of jurisprudence, without identifying its determinant grounds or demonstrating that the case under judgment conforms to those grounds" (item V) or "to cease to follow a statement of precedent, jurisprudence or precedent invoked by the party, without showing the existence of a distinction in the case under going judgment or the overcoming of the understanding" (item VI).

We can interpret "determinant grounds" in item V as ratio decidendi and $o b$ ter dictum, like we can do with "demonstrating that the case under judgment conforms to those grounds" as a way to apply precedents. In item VI we can read: "to cease to follow precedent" like overruling the precedent and "showing the existence of a distinction" as distinguishing, which are categories of the doctrine of precedents.

In other words: precedent now is binding; judges need to apply the ratio decidendi, to see and show what part of the precedent is obter dictum, with persuasive force. They can distinguish the cases, of course.

Article 926 from the new CPC determines that Courts must standardize their decisions and ensure that they remain "stable, integrated and coherent".

However, as we discussed above, it is important to understand that Courts in Brazil do not always respect their own decisions and sometimes even the decisions of higher courts. It is mandatory that judges justify their decisions, but it was not mandatory (at least until the new CPC) that they apply precedents.

In spite of this, Justice Teori Zavascki, from the Brazilian Supreme Court (STF), has said that the Brazilian Legal System is approaching Common Law, by respecting precedents in a slow but persistent way since $1963^{27}$, when the STF decided to publish súmulas, very short and synthetic-not analytical-(dockets of jurisprudence, abstracts or summaries of the decision), like "statutory $\mathrm{X}$ is unconstitutional" or "restaurants need do pay state tax on the sale of food and drink, instead of municipal tax". They have always been a persuasive force in rulings.

By Constitutional Act n. 45 of 2004, National Congress stipulated that Brazilian Supreme Court could publishes súmulas of its jurisprudence with binding force. Because of that, some jurists ${ }^{28}$ think that Parliament cannot stipulate bind-

26“Article 489. The following are essential elements of the judicial decision: [...].

$\$ 1^{\circ}$. No judicial decision, whether interlocutory, ruling or judgment, shall be considered to be justified, which: $[\ldots]$

$\mathrm{V}$-limit itself to invoking a precedent or súmula of jurisprudence, without identifying its determinant grounds or demonstrating that the case under judgment conforms to those grounds;

VI-to cease to follow a statement of precedent, jurisprudence or precedent invoked by the party, without showing the existence of a distinction in the case in judgment or the overcoming of the understanding.

${ }^{27}$ Brazil. Supremo Tribunal Federal. Reclamação 4.335 Acre. Plenário. Justice Teori Zavascki. Voto-vista, p. 6-21. Available at http://portal.stf.jus.br/.

${ }^{28}$ José Rogério Cruz e Tucci. "O regime do precedente judicial no Novo CPC", in Revista do Advogado. Ano XXXV, n. 126. São Paulo: AASP, 2015, p. 150. Cassio Scarpinella Bueno. Manual de direito processual civil. São Paulo: Saraiva, 2015, p. 538. 
ing precedents by court decisions in an ordinary statement (CPC is an ordinary law). By this construction, the Congress needs to issue Constitutional Act to bind precedents. Indeed, Judges in Brazil apply binding precedents just when there is súmula vinculante (binding dockets). In those binding dockets there actually is not any stare decisis as in Common Law decisions. As a matter of fact, the Brazilian Supreme Court has approved and published just 57 binding dockets (at least June 2020) since 2004, when a constitutional reform law approved it. In other words, considering that binding súmulas of Brazilian Supreme Court are a constitutional decision, binding precedents by a statute could be unconstitutional. It could be the case of CPC article 927, one that Congress stated how courts should work with precedents ${ }^{29}$.

It would be natural in common law systems that courts standardize their decisions and ensure they remain stable, integrated and coherent. However, this is not the case in Brazil, so Parliament decided that this reality must change. Judges and justices change their minds and interpret differently the same situation or statute so fast it is almost impossible or, at least rare, to talk about "the jurisprudence of one court". If it was the case, Parliament wouldn't need to constrain courts in a way like article 926.

In reality, however, the community will need more time to see if the Civil Procedure Code by 2015 produces the effects to stabilize judicial decisions and reduce the litigiousness. Five years is little time in judicial procedures to collect significant modifications.

\section{Conclusion}

Brazil participates in the Civil-Law tradition, has a legal constitution, and uncountable codes and acts. Despite the Constitution and the characteristics of the system, the system is not working well.

The Civil Procedure Code of 2015 was imported from the Common Law the theory of precedents in an attempt to confer stability to judicial decisions and 29“Article 927. The judges and the courts shall observe: I-the decisions of the Federal Supreme Court of concentrated control of constitutionality; II-the statements of binding precedent; III-judgments in an incident of assumption of competence or resolution of repetitive demands and in repetitive judgments of extraordinary and special resources; IV - statements of precedents by the Federal Supreme Court in constitutional matters and by the Superior Court of Justice in infra-constitutional matters; V-the orientation of the plenary or special body to which they are attached to.

Paragraph 1: The judges and the courts shall observe the provisions of art. 10 and in art. 489, $\S 1$, when they decide on the basis of this article.

Paragraph 2: The alteration of legal thesis adopted in a summary statement or in a trial of repetitive cases may be preceded by public hearings and by the participation of individuals, bodies or entities that may contribute to the re-discussion of the thesis.

Paragraph 3: In the event of a change in the dominant jurisprudence of the Federal Supreme Court and higher courts or in the possibility of repetitive cases, there may be a modulation of the effects of the alteration on the social interest and on legal certainty.

Paragraph 4: The modification of a summary statement, pacified case law or a thesis adopted in the case of repetitive cases shall observe the need for adequate and specific reasons, taking into account the principles of legal certainty, protection of trust and isonomy.

Paragraph 5: Courts shall publicize their precedents, organizing them by a decided juridical subject and disseminating them, preferably, in the world-wide computer network". 
legal security to society. However, if judges and justices do not apply the law all the time, merely to change the code will not be enough. Brazilian judges and justices must adjudicate similarly as judges and justices in the Common Law systems.

The data mentioned in this paper indicate that tax law is the subject of most of the lawsuits in Brazil. If judges and justices apply the Civil Procedure Code and the theory of precedents in tax law, there will be a significant reduction in judicial cases.

\section{Conflicts of Interest}

The author declares no conflicts of interest regarding the publication of this paper.

\section{References}

Andrews, N. (2012). O modern processo civil: Formas judiciais e alternativas de resolução de conflitos na Inglaterra (2nd ed. Rev.). at. e ampl. Orientação e revisão da tradução por Teresa Arruda Alvim Wambier. São Paulo: Revista dos Tribunais.

Brazil. Constitution of the Federative Republic of Brazil (3rd ed., p. 15). Biblioteca Digital da Câmara dos Deputados. Brasília.

http://english.tse.jus.br/arquivos/federal-constitution

Brazil. Justiça em Números 2016 (ano-base 2015). https://www.cnj.jus.br/

Brazil. Justiça em Números 2017 (ano-base 2016). https://www.cnj.jus.br/

Brazil. Justiça em Números 2018 (ano-base 2017). https://www.cnj.jus.br/

Brazil. Notícias do STF (December 12th, 2014). http://www.stf.jus.br

Brazil. Relatório Estatístico de 2018. http://www.stj.jus.br

Brazil. Superior Tribunal de Justiça. AgRg no REsp 382.736-SC. Publ. 03/03/2011. http://www.stj.jus.br

Brazil. Supremo Tribunal Federal. Reclamação 4.335 Acre. Plenário. Justice Teori Zavascki. Voto-vista (pp. 6-21). http://www.stf.jus.br

Bueno, C. S. (2015). Manual de direito processual civil. São Paulo: Saraiva.

Canotilho, J. J. G. (1991). Direito Constitucional. Coimbra: Almedina.

Cross, R. (2006). Statutory Interpretation (3rd ed.). Oxford: LexisNexis.

Cross, R., \& Harris, J. W. (2004). Precedent in English Law. Oxford: Clarendon.

Da Ros, L. (2015). O custo da Justiça no Brasil: Uma análise comparativa exploratória. Newsletter. Observatório de elites políticas e sociais do Brasil. NUSP/UFPR, v. 2, n. 9.

Delgado, J. (2011). A imprevisibilidade das decisóes judiciais.

Duxbury, N. (2008). The Nature and Authority of Precedents. Cambridge: Cambridge University Press.

Kravchychyn, J. (2010). Brasil, sozinho, tem mais faculdades de direito que todos os países. http://www.oab.org.br

Lee, J. (2011). From House of Lords to Supreme Court. Judges, Jurists and the Process of 
Judging. Oxford and Portland, OR: Hart.

Manchester, C., \& Salter, D. (2011). Manchester and Salter on Exploring the Law: The Dynamics of Precedent and Statutory Interpretation (4th ed.). London: Sweet \& Maxwell.

Marinoni, L. G. (2014). A Ética dos Precedentes: justificativa do novo CPC. São Paulo: Revista dos Tribunais.

Meissner, W. B. (2015). How to Explain Brazilian Civil Procedure in English. Curitiba: Juruá.

Raz, J. (2009). Between Authority and Interpretation: On the Theory of Law and Practical Reason. Oxford: Oxford University Press. https://doi.org/10.1093/acprof:oso/9780199562688.001.0001

Tucci, J. R. C. (2015). O regime do precedente judicial no Novo CPC. Revista do Advogado, 35, 150.

United Kingdom (2015). The Supreme Court Annual Report and Accounts 2014-2015 (p. 26). https://www.supremecourt.uk/docs/annual-report-2014-15.pdf

United States of America (2015). The Leadership Conference. https://civilrights.org/judiciary/federal-court-system/u-s-supreme-court

Zander, M. (2015). The Law-Making Process (7th ed.). Oxford and Portland, OR: Hart. 